\title{
Online Marketing by Private English Tutors in Chile: A Content Analysis of a Tutor Listing Website
}

\author{
Olusiji Lasekan \\ Universidad Católica de Temuco, \\ Temuco, Chile \\ Ana Moraga \\ Universidad de La Frontera, \\ Temuco, Chile \\ Alejandra Galvez \\ Universidad Católica de Temuco, \\ Temuco, Chile
}

\begin{abstract}
To provide business advice for Chilean pre-service and inservice English teachers who are aspiring to become a private English tutor, this study seeks to investigate the price charged for English private tutoring services and assesses the impact of tutors' years of experience on the lesson's price charged per hour by private tutors. A random sample of over one-twenty individual English tutor profiles advertising on a Chilean tutor listing website was considered. The results of the quantitative analysis indicate that the majority of Chileans private English tutors charged between 11000 and 15000 Chilean pesos for English for General Purposes per hour. Other major findings include a weak negative correlation between the tutors' years of experience and tuition fees charged by them. Implications of the results and future research directions are also presented.
\end{abstract}

Keywords: English Private Tutoring Industry; Marketing; Website; Shadow Education; Mainstream Education; Chile.

\section{Introduction}

Tutoring is a very lucrative business that allows teachers to earn extra income (Foondun, 2002). Its lucrativeness is one of the leading forces driving the demand of English private tutoring in Chile. As entrepreneurs, English tutors offer various branches of EFL tutoring services to private individuals at their own homes or in their clients' homes (Lasekan, 2019). The primary area of services includes English for General Purposes (EGP) otherwise known as 
'TENOR'- the teaching of English for No Obvious Reason' (Abbot, 1981 in Jordan, 1997, p.4) and English for Specific Purposes (ESP) which deals with training of learners to communicate effectively in an academic or professional setting (Dudley-Evans \& Jo St John, 1998). Clients for EGP are described as learners who possess no compelling motive to learn the language. It is characterized by tutoring structural or grammatical aspects of the English language to help the tutees to pass major English proficiency exams (Hutchinson \& Waters, 1987). The service can also be considered as a supplemental education for students from kindergarten to university seeking English teaching services so that they can improve in their performance in the mainstream classroom. These services can be divided into spoken (voice), written, and grammar (non-voice) (iValue Consulting Private Ltd, n.d.). The study further divide spoken English lessons into conversation class and pronunciation. Based on the current level of proficiency of the clients, their needs can be met by offering different levels of English proficiency services such as elementary, primary, pre-intermediate, intermediate, and advanced levels of English.

Furthermore, it is possible to have clients beyond the K-12 education system (Lasekan, 2019). The author anchored their primary motivation on the immediate need for English service to secure employment in foreign countries or seek admission into universities in English-speaking countries for postgraduate education. Such a group of clients seeks for IELTS or TOEFL exam preparation tutors. ESP's clients are also part of this group. They are mostly Professionals in various multinational companies. The demand stems from the need to handle English demand job-performance tasks (Rodriguez, 2013). In sum, the primary English tutoring service includes EGP, ESP, and IELTS/TOEFL exam preparation tutoring services.

What is known about private tuition service is mostly based on empirical studies that focus on factors that influences its increasing demand (Bray \& Kwok, 2003; Davies, 2004) and its impact on tutee's performance in the mainstream education system (Dang, 2007; Berberoğlu \& Tansel, 2014). Consequently, it led to studies on online advertising of private tutors in various academic subjects (Holloway \& Pimlott-Wilson, 2019; Kozar, 2013). The increasing interest in this new area of research can be attributed to the following reasons;

Firstly, the decisive role of online marketing in promoting goods and services (Lagrosen, 2005). This is essential considering that in an unorganized and unregulated private tutoring industry such as the one in Chile, choosing or identifying an excellent tutor for hiring due to fraudulent misinformation on the Internet (Koo \& Skinner, 2005) or paying for the service at its right price as a result of lack of trust in e-commerce (Chong Yang \& Wong, 2003) can be challenging. To foster consumers' confidence in the industry, several studies on private tuition market surveys have emerged in different settings (Tanner et al., 2009; Foondun, 2002).

Furthermore, it is due to the causal effect between demand and supply of Private tutoring services (Jokić \& Dedić 2013, p. 24). This effect is critical because 
understanding the dynamics of shadow education helps in analyzing the nature and trends of private tutoring and its impact on society and mainstream education systems (Št'astný, 2017). In other words, the existence of private supplementary tutoring depends on both the demand for it and the supply of it (Dang \& Rogers, 2008). For example, the Chilean government's plan to meet the development goals by attaining the status of a developed country before the year 2020 has spiked the demand for learning the language among the citizens (Byrd, 2013). This demand has reinforced the service providers to make the services available and recommend students to take advantage of the availability through online marketing (Bray 2009, 79-80). Thus, the English Private Tutoring (EPT) industry, as a reflection of the mainstream English language education system, might suggest a positive correlation of variables in both settings (Bray, 2010). It is critical to know the degree at which variable factors such as tutors gender composition, cost of tutoring per hour, and teaching experience reflect that of mainstream English language education. All these insights will help aspiring private English tutors in making an informed decision concerning the price of the services. Thus, the primary purpose of this study is to firstly evaluate the socio-demographic background such as gender and professional profile of individual private English tutors advertising online and their distribution in Chile and then determine the cost of tuition fee charged per hour for EGP, the gender composition of the tutors, the proportion of local and foreign tutors, the range of tutors' years of experience and the correlation between the cost price charged for EGP and tutors' years of experience. The study begins by reviewing variable factors that shape a mainstream English language education. This approach is vital to compare the same variable factors as that of EPT. Data for this study are collected from publicly available information on tutor listing websites. Both descriptive and inferential statistics are adopted to analyze the data. Data analysis is followed by a discussion on which conclusions are later drawn.

\section{Literature review}

Tutoring is a practical way of teaching a student or a small group of students to receive customized and personalized instruction (Medway, 1995, p. 271). This concept has shaped the different authors' views while defining Private Tutoring (PT), sometimes called Private Supplementary Tutoring (PST). From the tutor's point of view, tutoring involves the teaching of subjects or courses as a way to earn extra income (Kinyaduka, 2014). However, from the tutees' point of view, it is a fee paid to a tutor to gain supplementary instruction in an academic subject being studied in Mainstream Education (ME) (Dang \& Rogers, 2008). Thus, PT has two main characteristics. Learners must be paying the instructors, and learning should be supplementary to the one in receiving in the ME system.

The demand for private tuition is based on the contrast between public and private schooling (James, 1987). This contrast was explained by differentiating between excess demand and differential demand. The author argued that excess demand occurs when every child cannot access excellent or adequate quality public schools because they are limited in capacity. Therefore, the private school meets the excess need even if they are not as good as the public school. On the 
other hand, differential demand is described as a situation whereby parents choose to enroll their children in private schools because they are superior in quality. However, in PT, the demand can be both excess and differential. According to the author, it is excess when the students and the families feel the mainstream education system is not meeting their needs, and the services are expected to be provided by the same tutor that tutee has in that system.

On the other hand, it can be differentiated when the tutor offers a curriculum that is different from that of the ME (James, 1987). The author maintains that the service is usually provided by the specialist tutor who does not already have responsibility for the tutee whom they tutor. In sum, the demand the increasing demand for PT stemmed from an impaired education system (Bray, 2007).

The effect of private tutoring on students' achievement in schools is marred with inconsistent findings. Concerning international exams such as SAT and ACT, Briggs (2001) adopts a linear model to establish a relationship between students' enrollment in PT and their performance in the exams. In a Year 5 Scholarship Exam, a high-stakes national exam in Sri-Lanka, Cole (2016) study revealed that five months of tutoring has no significant impact on students' performance in the exam. But in comprehensive research conducted by Lee (2013), PT among the middle school students is reported to have a positive short-term effect on their academic achievement in English and Maths but has a minimal long-term impact on the university entrance examination scores. Though academic achievement English and Maths are boosted, verbal tutoring is not. The main reason for these inconsistent results can be attributed to the difference in additional learning time, quality of tutoring, students' motivation and engagement (Mori, 2012).

The positive and the negative implication on mainstream education as a whole have been stressed in the body of literature (Foondun, 2002; Carr \& Wang, 2018). Some of the positive impacts of the PT range from being able to give special attention and help weak students (Foondun, 2002). The author states that such special attention can be challenging to deliver due to the overcrowded classroom and limited teaching hours. Unlike typical classes, the author also believes that tutees socialize better in private tuition due to a lack of regulations and restrictions. On the other hand, scholars have expressed the unethical part of private tutoring, which has led to the reduction of teachers' commitment to mainstream education (Sawhney \& Landran, 2018). For example, private tutoring is made mandatory to students by some teachers. This unethical practice involves teaching part of a topic in a subject and reserve the rest for their private classes (Bray, 2003). Such practice can lead to devaluation of classroom study. A situation whereby some students decide to be absent or not paying attention when a lesson learned in PT is repeated in class (Foondun, 2002). Also, PT has been found to accentuates the socio-economic inequalities among students since most students may not be able to afford it (Safarzyńska, 2011). This inequality consequently erodes the benefits that poor students can get from such a system. Taken together, PT is accompanied by both negative and positive implications. 
The instrumental motivation to learn English in both ESL or EFL contexts has led to increasing demand for English private tutoring (EPT) classes in those spaces. Consequently causes more scholars in linguistics, education, and economics to delve into English private tutoring research (Pallegedara, 2012; Kim \& Park, 2010). A particular study works on the effect of one-year English tutoring on grade 9 students, and it was found that students' performance improves significantly in their respective schools (Lee, 2013). Another study is interested in why underprivileged are investing in EPT (Yung, 2019). The result shows that other than to enhance their English proficiency, English private tutoring classes are suitable spaces to expand their social network and to boost their self-esteem. In Jordan, three reasons that promote the EPT industry were identified. These are the prestige and importance of English, the need to understand science subjects which are taught in English, and the affordability of such service (Khuwaileh \& Al-Shoumali, 2001). The need to obtain certified international English proficiency is also a huge factor (Memon \& Umrani, 2016), many students are enrolling for private tutoring for IELTS/ TOEFL exam preparation to fulfill the requirement to access further education or employment in English speaking countries. Overall, the current debate is centered on the importance of EPT and factors that are boosting its industry.

Recent studies have stressed the demand and supply of private tuition in all academic subjects (Št'astný, 2017; Kozar, 2013). The main goal is to express the role of online marketing to evaluate demand and supply. A study in this regard focused on demographics and presentation styles of the tutor (Kozar, 2013). Another study assesses the micro- and macro- variable factors that influence the advertised tuition fee (Št'astný, 2017). The only work that deals with private English tutors 'personalities to promote their competence online is the work of Yung (2019). In the author's discourse analysis paper, English tutors portray the identities of an experienced exam expert, a famous star, and a well-qualified English language teacher. It can argue that scholars are more interested in the private tutoring industry as a whole with less attention to subject-specific PT, such as English.

The definition of shadow education as a symbol of private supplementary tutoring is based on the premise of supplementation (tutoring which focuses on subjects which are already covered in school), privateness (tutoring provided in exchange for a fee) and academic subjects (such as language, maths, and other examinable subjects) (Bray,1999). The author opined that the metaphor of a shadow is appropriate because its existence, as well as size and shape, are based on that of mainstream education. In other words, variable factors such as gender composition, cost of education and teaching experience that shaped mainstream education are supposed to mirror that of private supplementary tutoring.

Studies on the cost of mainstream higher education showed that tuition fee in Chile is the second most expensive in the world (Muñoz \& Radics, 2017). This can be attributed to a high degree of privatization of both secondary and higher education (Torche, 2005). However, as far as English language education in K-12 education is concerned, students in typical expensive private schools have been 
found to perform better than their counterparts in public schools (Council, 2015). The study attributed this disparity to more hours dedicated to learning the language and better quality experienced teachers. Schools with a higher number of teachers with advanced experienced is an indication that the schools pay higher remuneration to the teachers (Behrman et al., 2016). This higher remuneration is one of the factors that make private schools more expensive than the public.

On the other hand, several factors that influence the price of a lesson charged per hour in PT depends on the frequency of lessons taken, the duration of the lessons, the subject taught, teachers quality, the mode of lessons (one to one/ groups) and geographical location (Hamid, Sussex, \& Khan, 2009). The impact of the latter on price has not been consistent. Tanner et al. (2009) found that the degree of distance between the tutor and tutee determines the price, but in a study conducted in Czech Republic context showed that tutors who offer to commute to students' residence charge less than those who do not provide this service (Š́tastný,2017). Thus, connecting the cost of tuition fees in mainstream education to that of PT is not feasible because the price being charged in the EPT industry is influenced by several factors. However, the gap that needs to be filled in the body of literature is the fee charged by private English tutors and the role that years of teaching experience plays in the cost fee.

Regarding region with most available services, studies have shown that more populated cities, which are usually the capital or industrial cities of a country, account for the most significant tutoring services compared to rural areas. Factors such as the volume of higher income earners who can easily afford tutoring services for themselves or their children and the population density of the top income earners have been used to explain this result (Bray, 2011). However, in a study reported in Poland indicated that $57 \%$ of upper-secondary students from cities were actively involved in private lessons compared to $70 \%$ from rural areas (Długosz, 2016, p. 181). That shows that other than population density, several other factors determine the degree of advertisements for private tutoring services in different regions.

With respects to the gender composition in mainstream education, research shows that the teaching profession is dominated by women (Tašner et al., 2017; Drudy, 2008). Evidence from different parts of the globe showed that female teachers account for the most significant percentage of the teaching workforce (Kelleher et al., 2011). This gender imbalance in the teaching profession has been linked to factors such as economic development, urbanization, women's place in society, masculinity's cultural meaning, and the importance of children and childcare (Drudy et al., 2005). An empirical study to explain this phenomenon includes investigation on enrollment of male and female students. The findings have not been consistent. In the case of India, male students of about $54 \%$ were found to be enrolled in PT (Sujatha, 2014). But research on students with similar backgrounds conducted in Ireland has shown that PT accounts for over $60 \%$ of female students (Smyth, 2008). Overall, it is clear that there is yet to be a study determining the gender composition of tutors in PT. Such data is needed to 
compare the level of gender imbalance between mainstream education and the PT industry.

The competence of untrained English native speakers has been a subject debated in mainstream English education over the years. It ranges from their performance in the classroom compared to non-native speakers (Tosuncuoglu, 2017). The attitude of students towards native and non-native English speaking teachers (Todd \& Pojanapunya, 2009) and preference of employers to hire native English speakers without teaching credentials over qualified non-native English speakers has been proven in several contexts (Porras, Ee \& Gándara, 2014). This preference has consequently increased their percentage in the English teaching profession in most EFL countries. However, their percentage in EPT has been elusive in the body of literature.

Given all that has been mentioned so far, the size and shape of mainstream English language education are influenced by numerous variable factors. The key research question of this study was whether or not the variable factors in mainstream English language education correlate with its shadow (English private supplementary education). Thus six main research questions will be examined;

1. What are the ranges of tuition fees charged for EGP per hour?

2. What is the percentage of tutors offering ESP and English proficiency exams tutoring services?

3. What are the percentage ranges of Private English tutors' years of experience?

4. What is the percentage of qualified and unqualified teachers?

5. What is the gender composition of Private English tutors in the industry?

6. Which city has the most available English private tutoring services?

7. What is the correlation between tutors' years of experience and their charges for EGP per hour?

\section{Methodology}

\subsection{Data source}

To date, previous studies have adopted tutors' profiles on web portals and websites as a useful source for data collection (Bryman, 2012, p. 654: Tanner et al., 2009). The only drawback associated with relying on internet profiles is its credibility (Kozar, 2013). It is believed that the tutor's profile may not necessarily be portrayed accurately because of the self-report bias effect (Rosenman, Tennekoon \& Hill, 2011). Thus, the author advises that an online profile needs to be strictly viewed as a self -presentation of individuals offering PT services and seeking clients via a specialized website. The author also suggests that researchers acknowledge this concern of data authenticity while interpreting and reporting the result of such data sources. However, data collection on the tutor listing website can be regarded as an archival material that has an advantage over volunteered based research (Hatch, 2002). 


\subsection{Website selection}

The procedure for initial internet pre-screening began in October of 2019. It involves using the most popular search engine called Google. It was chosen because it symbolizes the current state-of-the-art online search technology, and it serves the most significant percentage of queries (approximately $47.3 \%$ ) on the Internet, with an index of around 25 billion Web pages and 250 million queries a day (Bertolucci, 2007). The search for "ingles particulares en Chile" translation (English private tuition in Chile) suggested there were several websites that private tutors advertise their services. While some of the websites charge prospective users a certain amount of fee for its usage, some offer free advertisements for all prospective users. Similar to Št'astný (2017) observation, all the websites can be divided into notice boards and mediated notice boards. While the former is in form of simple texts describing a particular offer, but with non-standardized content with diverse information regarding the character of the private English lessons, the latter website is designed to express standardized presentations of tutors' profile with information on qualifications, offered subjects, price, residence amongst others.

The criteria needed for selecting the website for this study is that the tutor listing website should be free. It is based on the assumption that free sites will be widely patronized, consequently offer a plethora of profiles for analysis. Secondly, the website must be mediated notice board because it demonstrates standardized presentations (profiles). It aids in easy and accurate coding information and quantification of data gathered from the website.

The two largest tutor-listing websites that meet these criteria are yapo.cl and tuparticulares.cl. yapo.cl is a Chilean website dedicated to advertising goods and services of all kinds. It is not a specialized website for advertising private tutoring services. The standardization of mediated notice board tutors' profiles include name, cost of the price charged per hour, location, offered service, and description for tutors' introduction. On the other hand, tuparticulares is an international company that exists in several countries. The website is designed for connecting tutors with potential tutees. The mediated notice board of the web portal contains detailed information which ranges from tutors' name, location, contact details, service offered, years of experience, cost of tuition, hours of availability and description space for tutors to share other necessary info. Finally, all profiles on the website are verified with the data verified icon and it possesses reviewers' comment section where tutees are rating tutors.

After analyzing these two websites, web-portal tuparticulares.cl meets the criteria mentioned above to the highest degree. The choice is also based on the fact that the tutor profile can be verified with photo and reviewers' comment feature. These verifications foster the reliability of the data available on the webpage.

\section{Data analysis}

To make generalizations from the data collected via the tutor listing website, the author adopted purposive sampling (Etikan, Musa \& Alkassim, 2016) to analyze over 120 tutors' profiles. Answering the first question regarding the city with the 
most available tutoring service, this study chose to adopt both profiles in yapo and tupaticulares. The objective is to determine the city with a high level of patronage on both websites. Other variables analyzed on tuparticulares.cl are different ranges of the percentage of EGP tutors, percentage of tutors' years of experience, cost price charge per hour, gender composition, percentage of tutors in different EPT, gender composition in the industry, and percentage of tutors with credentials.

This is followed by acquiring and assembling data from the website, and all the information is coded. The data was processed and further analyzed using spreadsheet software Microsoft Excel and SPSS to undertake descriptive and inferential statistics.

\section{Results}

Descriptive statistical analysis was used to quantify all the variable factors except the inferential statistical analysis used to correlate the teaching experience and the price cost charge for EGP per hour.

Figure 1 presents an overview of the cost price charge for EGP per hour. It is apparent from this table that the majority of tutors' charge is between 1100015000 Chilean peso. It is followed by a $35 \%$ group of tutors that charge over around 16000-20000 Chilean peso.

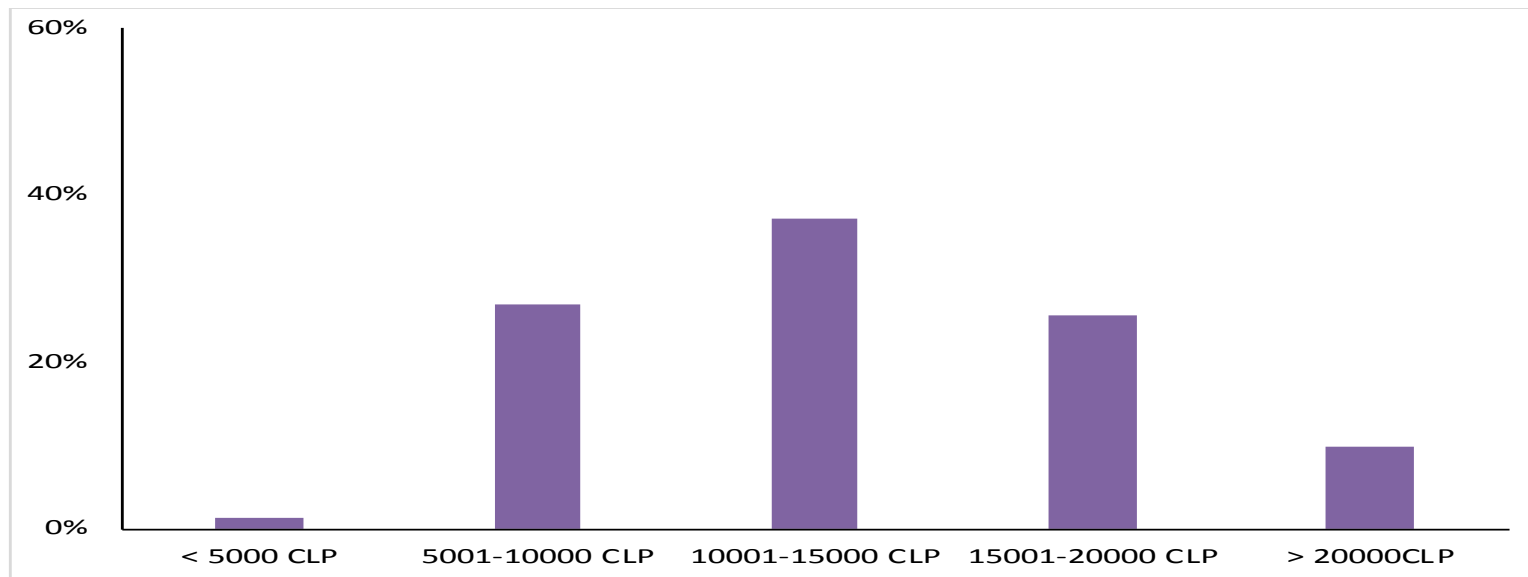

Figure 1. A chart showing a relationship between the percentage of tutors and the tuition fee they charge.

If we now turn to Figure 2, it illustrates the percentage of teachers that teach English proficiency exams and ESP. It can be seen that most tutors offer IELTS/TOEFL exam. 


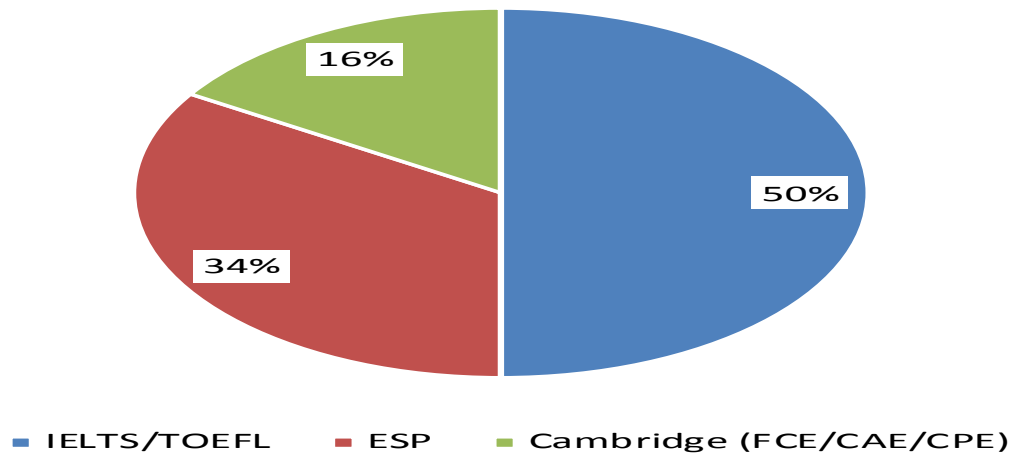

Figure 2. A chart showing the percentage of tutors offering different English courses

Turning now to the experimental evidence on the tutors' years of experience, it is quite revealing that most tutors' years of teaching ranges between 6 and 10 years

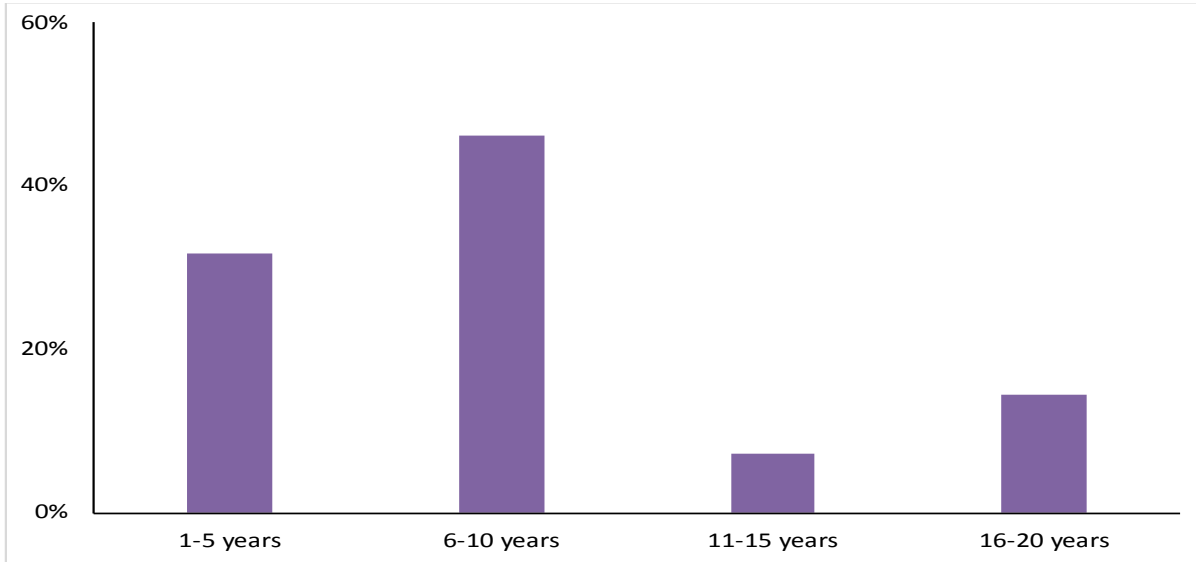

Figure 3. A chart showing the relationship between tutors and their years of tutoring experience

The next section of the survey was concerned with the percentage composition of qualified Chilean English teachers and native English speaking tutors without teaching credentials. It is interesting to know that $64 \%$ of Chileans teachers of English dominate the industry.

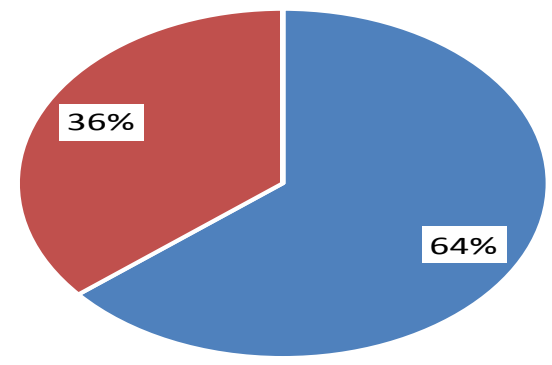

- Qualified Chilean English teachers

- Native English teachers (with no teaching credentials)

Figure 4. A chart showing the composition of Chilean English tutors and Native English tutors with no teaching credentials. 
Regarding the gender composition in the industry, it can be seen from figure 5 females account for over $60 \%$ of the industry.

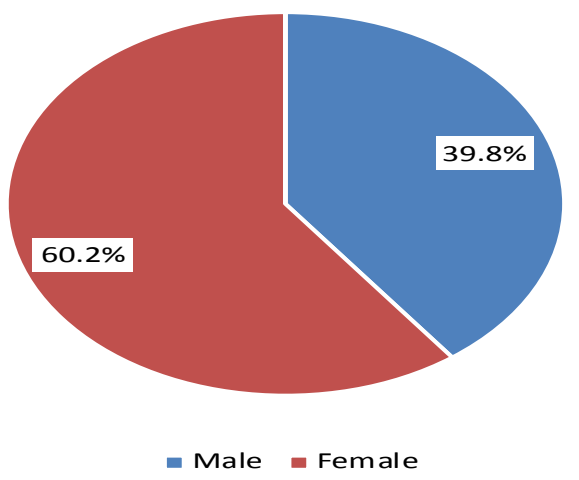

Figure 5. A chart showing genders'composition of tutors in the industry

Regarding the quantification of English tutoring service advertised in different locations on yapo and tuparticulares within 6 months, it can be seen in Figure 6 that most of the adverts emanate from Santiago while Figure 5 shows that adverts from other cities are more than that of Santiago.

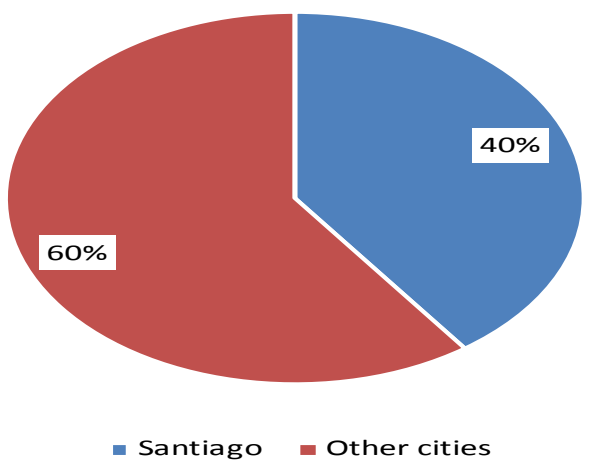

Figure 6. A chart showing the percentage of tutors offering their services in different cities of Chile on yapo.cl

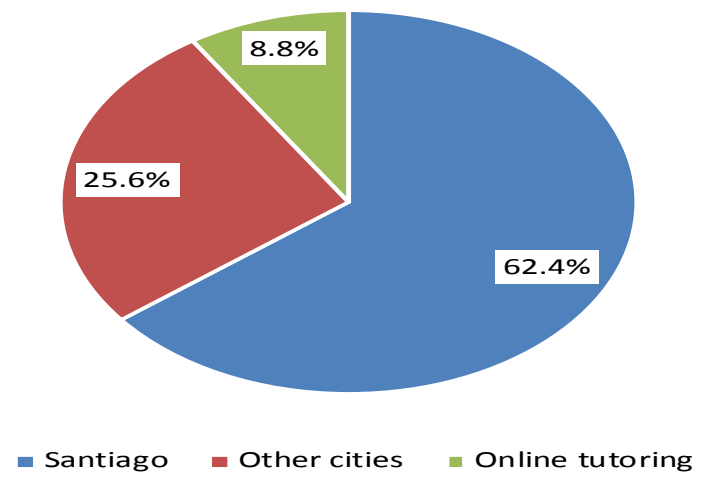

Figure 7. A chart showing the percentage of tutors offering their services in different cities of Chile on tuparticulares.cl 
In the final part of the survey, the degree of correlation between tutors' years of experience and the charged tuition fee per hour was carried out. A weak negative correlation (-.394) was found between the two variables.

Table 1

Correlational analysis of tutors' years of experience and their service fee

\begin{tabular}{|c|c|c|c|c|}
\hline \multirow{7}{*}{ Rho de Spearman } & \multirow{4}{*}{ Experiencie } & & Experiencie & Cost \\
\hline & & $\begin{array}{l}\text { Coeficiente de } \\
\text { correlación }\end{array}$ & 1.000 & $-.394^{*}$ \\
\hline & & Sig. (bilateral) & . & .035 \\
\hline & & $\mathrm{N}$ & 29 & 29 \\
\hline & \multirow[t]{3}{*}{ Cost } & $\begin{array}{l}\text { Coeficiente de } \\
\text { correlación }\end{array}$ & $-.394^{*}$ & 1.000 \\
\hline & & Sig. (bilateral) & .035 & . \\
\hline & & $\mathrm{N}$ & 29 & 29 \\
\hline
\end{tabular}

*. La correlación es significativa en el nivel 0,05 (bilateral).

\section{Discussion}

The first question in this study sought to determine the cost of tuition fees charged per hour for EGP. The current study found that the majority (37:2\%) of the tutors charge between 11000 and 15000 Chilean pesos. This group is followed by $(26 \%)$ of tutors who charge between 6000 and 10000 Chilean pesos. Since there is no prior cost survey of EGP in other EFL contexts, it is difficult to compare the service fee in Chile with other countries. However, the differences in the fee ranges might have been influenced by different factors such as frequent lessons, teachers' quality and geographical location (Hamid et al., 2009) The second objective of the study was to identify the volume of English Private Tutoring (EPT) services' adverts in different regions of Chile. The result indicates that tutor list websites such as yapo.cl have more EPT service adverts from different regions of Chile than in Santiago, which is the capital city of the country. On the other hand, tuparticulares has more adverts from tutors residing in Santiago than those living in the other regions of Chile. Though previous findings have not been consistent in this regard. However, this is the first study to compare the availability of services in different locations on two different tutor listing websites. A possible explanation for these results may be because yapo is a Chilean company which is known for advertising all goods and services. Thus, it is more popular all over Chile, while tuparticulares as an international tutor listing website is more popular in an international city such as Santiago. Based on the consumer's location, these findings have a crucial implication in tutors' and consumers' decision making concerning the choice of tutor listing websites for advertising their service.

In the literature review, no data was found on the gender composition of tutors in the EPT industry. In this study, $60.2 \%$ of females are accounted for in the industry. This result matches those observed in mainstream education (Drudy et al., 2005). The author speculated that the role of feminization in the teaching profession is responsible for the gender imbalance in the education industry. That suggests that gender composition in the EPT industry reflects that of 
mainstream education. Further study on motivational factors that influence both male and female tutors to work in this industry need to be conducted.

Very little was found on the question of private English tutors' years of experience. Surprisingly, the present study indicates that most tutors $(46.3 \%)$ have 6 to 10 years of experience in tutoring. This is followed by those with more recent years of experience $(13 \%)$. The findings demonstrate that most tutors began their careers around ten years ago. Considering the fact that English was introduced into the national curriculum in 1998, it is plausible that many teachers began entering into EPT industry for about ten years. Thus, this finding can be used to predict the beginning and growth of the industry. Further research should be done to investigate the historical account of EPT industry in Chile.

In mainstream education, a positive correlation between teachers' wage and their years of teaching experience have been reported (Behrman et al., 2016). But in EPT, the result shows a weak negative correlation $(\mathrm{p}<.05, \mathrm{r}=-.394)$ between tutors' years of experience and the fee they charge. In other words, the higher the years of tutoring experience, the lower the tutoring fees being charged. This finding is contrary to what is obtainable in mainstream education. The tendency for experienced Chilean private English tutors to charge less is plausible. Because the higher their wages in mainstream education, the lesser the fee they charge in the EPT industry. Considering that the motivation to join the industry is mainly to earn extra income.

As mentioned in the literature review, native English speaking teachers without credentials have been favored for teaching jobs at the expense of qualified nonnative English speaking teachers (Porras, Ee \& Gándara, 2014). The result emerges from the data is that Chileans English teachers dominate the industry with over $(60 \%)$. Therefore, the findings of the current study do not reflect those conducted in mainstream English education. This somewhat contradictory result may be due to the fact the EPT industry is not attractive to native English speakers (NES) because the market charged price is not attractive to them. Another possible explanation is that Chilean tutees prefer Chilean English teachers with the necessary qualifications to native English speakers with no teaching qualifications. While interpreting these results, it is essential to state that not all the tutors considered for this study are NES. Some are Chileans but have lived most of their life in English speaking countries.

The majority of Chileans are either pursuing a higher degree of education in English speaking countries or seeking greeners pasture in English speaking countries. It is revealed in the current study that shows that over $50 \%$ of tutors are offering either the IELTS/TOEFL preparation exam service. This finding is in agreement with results that showed an increasing demand for the IELTS exam in Pakistan (Memon \& Umrani, 2016). Though the percentage of tutors offering ESP tutoring service is around $30 \%$, it is interesting to know that a few tutors are offering service of ESP in Chile. Considering that ESP as a subject is not part of 
the English teachers' training curriculum. It is likely teachers are trained during their in-service professional development program.

\section{Conclusion}

The purpose of the current study was to determine characteristics of English Private Tutoring (EPT) services and the degree to which these characteristics such as tutors' years of experience influence the tutoring service charge set by the tutors. Based on the analysis of English private tuition service advertised on the Chilean website, the result shows the majority of tutors' service charge is between 11000 and 15000 Chilean pesos, though the service charge is weakly negatively correlated with their years of tutoring experience. The study has also found that the cities with the most available services vary from one website to another. Another major finding of this investigation is that EPT as an industry is dominated by female tutors and qualified Chilean English teachers. Finally, IELTS/TOEFL examination preparation service is the most available service other than typical EGP. These findings suggest that the factors that shape the EPT industry are diverse. It ranges from gender, tutors' experience, the adopted website for advertisement, and available branches of English tutoring services. Since some of these factors reflect that of mainstream education, it is evidence that EPT is the shadow education of the mainstream English education.

This is the first study to provide a deeper insight into the Chilean EPT industry. It can be used to offer business advice for aspiring English tutors who want to work full or part-time in the industry. Finally, the article has also addressed the gap identified by Št'astný (2017), who calls for studying private tutoring supply from a comparative point of view in multiple countries.

The findings in this report are subject to at least three limitations. First, it is void of an undisclosed number of private tutors who regularly offer private lessons but do not advertise online. Second, as the sampling was done purposively, the findings cannot be applied to the entire population of tutors advertising online. Third, as already pointed out in previous studies, (Kozar 2013, p. 78; Stastny, 2017), it is important to recognize that online profiles might not always equate to real-life facts and should instead be regarded as a self-presentation of individuals offering their services.

This research has thrown up many questions in need of further investigation. For example, it would be interesting to assess the motivational factors of English tutors to join the EPT industry. Such an investigation will offer more perspectives on the characteristics of the industry. From pedagogical stands point, it would be interesting to explore pedagogical skills express in English tutoring class. 


\section{References}

Abbott, G. (1981). Approaches to English teaching. The teaching of English as an international language: A practical guide. London: Collins.

Behrman, J. R., Tincani, M. M., Todd, P. E., \& Wolpin, K. I. (2016). Teacher quality in public and private schools under a voucher system: The case of Chile. Journal of Labor Economics, 34(2), 319-362.

Berberoğlu, G., \& Tansel, A. (2014). Does private tutoring increase students' academic performance? Evidence from Turkey. International Review of Education, 60(5), 683701.

Bertolucci, J. (2007). Search engine shoot-out. PC World, 25(6), 86-96.

Bray, T. M. (1999). The shadow education system: Private tutoring and its implications for planners. UNESCO International Institute for Educational Planning.

Bray, M. (2003). Adverse effects of private supplementary tutoring: Dimensions, implications, and government responses. UNESCO. Instituto Internacional de Planeamiento de la Educacion

Bray, M. (2010). Researching shadow education: Methodological challenges and directions. Asia Pacific Education Review, 11(1), 3-13.

Bray, M. (2011). The challenge of shadow education: Private tutoring and its implications

Bray, M., \& Kwok, P. (2003). Demand for private supplementary tutoring: conceptual considerations, and socio-economic patterns in Hong Kong. Economics of Education Review, 22(6), 611-620.

Bray, T. M. (1999). The shadow education system: Private tutoring and its implications for planners. UNESCO International Institute for Educational Planning.

Briggs, D. C. (2001): The Effect of Admission Test Preparation: Evidence from NELS - 88. Chance, 14(1), 10-18.

Bryman, A. 2012. Social Research Methods. New York: Oxford University Press Inc.

Byrd, K. (2013). Reactions to English Language Learning in Chile as a Means for Personal and National Development

Carr, D., \& Wang, L. C. (2018). The effect of after-school classes on private tuition, mental health, and academic outcomes: Evidence from Korea. Sociology, 52(5), 877-897

Chong, B., Yang, Z., \& Wong, M. (2003, September). Asymmetrical impact of trustworthiness attributes on trust, perceived value and purchase intention: a conceptual framework for cross-cultural study on consumer perception of online auction. In Proceedings of the 5th international conference on Electronic commerce (pp. 213-219). ACM.

Cole, R. (2017). Estimating the impact of private tutoring on academic performance: primary students in Sri Lanka. Education economics, 25(2), 142-157.

Council, B. (2015). English in Chile: An examination of policy, perceptions and influencing factors, Santiago.

Dang, H. A. (2007). The determinants and impact of private tutoring classes in Vietnam. Economics of education review, 26(6), 683-698.

Dang, H. A., \& Rogers, F. H. (2008). The growing phenomenon of private tutoring: Does it deepen human capital, widen inequalities, or waste resources? The World Bank Research Observer, 23(2), 161-200.

Davies, S. (2004). School choice by default? Understanding the demand for private tutoring in Canada. American Journal of Education, 110(3), 233-255.

Długosz, P. (2016). Private Lessons as an Instrument for Middle Class Status Struggle in Post-socialist Societies: Poland and Ukraine Case Studies. doi:10.14254/2071789X.2016/9-1/12. 
Drudy, S. (2008). Gender balance/gender bias: The teaching profession and the impact of feminisation. Gender and education, 20(4), 309-323.

Drudy, S., Martin, M. Woods, M. \& O'Flynn, J. (2005) Men and the Classroom: Teachers in Today's Primary Schools. London: Routledge.

Dudley-Evans, T., St John, M. J., \& Saint John, M. J. (1998). Developments in English for specific purposes: A multidisciplinary approach. Cambridge university press.

Etikan, I., Musa, S. A., \& Alkassim, R. S. (2016). Comparison of convenience sampling and purposive sampling. American journal of theoretical and applied statistics, 5(1), $1-4$.

Foondun, A. R. (2002). The issue of private tuition: an analysis of the practice in Mauritius and selected South-East Asian countries. International review of Education, 48(6), 485-515.

Hamid, M. O., Sussex, R., \& Khan, A. (2009). Private tutoring in English for secondary school students in Bangladesh. Tesol Quarterly, 43(2), 281-308.

Hatch, J. A. (2002). Doing qualitative research in education settings. Suny Press.

Holloway, S. L., \& Pimlott-Wilson, H. (2019). Marketising private tuition: Representations of tutors' competence, entrepreneurial opportunities and service legitimation in home tutoring business manuals. British Educational Research Journal.

Hutchinson, T., \& Waters, A. (1987). English for specific purposes. Cambridge university press.

iValue Consulting Private Ltd., English language training market India: Market opportunity report. Retrieved from www.britishcouncil.in/sites/britishcouncil\&/draft_elt_report_24_dec.pdf

James, E. (1987). The public/private division of responsibility for education: An international comparison. Economics of Education Review, 6(1), 1-14

Jokić, B., Soldo, A., \& Dedić, Z. R. (2013). Private tutoring and social equity in Croatia and Bosnia \& Herzegovina: a comparative qualitative study. In Private tutoring across the Mediterranean (pp. 11-27). Brill Sense.

Jordan, R. R. (1997). English for academic purposes: A guide and resource book for teachers. Cambridge University Press.

Kelleher, F., Severin, F. O., Samson, M., De, A., Afamasaga-Wright, T., \& Sedere, U. M. (2011). Women and the teaching profession: Exploring the feminisation debate. Unesco.

Khuwaileh, A. A., \& Al-Shoumali, A. (2001). Private tuition in English: the case of two universities in Jordan. English Today, 17(1), 31-35.

Kim, J. H., \& Park, D. (2010). The determinants of demand for private tutoring in South Korea. Asia Pacific Education Review, 11(3), 411-421.

Kinyaduka, B. D. (2014). Private tutoring: A critical analysis of world experiences. Merit Research Journal of Education and Review, 2(8), 135-140.

Koo, M., \& Skinner, H. (2005). Challenges of internet recruitment: a case study with disappointing results. Journal of Medical Internet Research, 7(1), e6.

Kozar, O. (2013). The face of private tutoring in Russia: Evidence from online marketing by private tutors. Research in Comparative and International Education, 8(1), 74-86

Lagrosen, S. (2005). Effects of the internet on the marketing communication of service companies. Journal of services marketing, 19(2), 63-69.

Lasekan, O. A. (2019). How well prepared are Chilean beginning English teachers to meet job demands in English language teaching industry? Journal of Entrepreneurship Education, 22(6). 
Lee, J. Y. (2013). Private tutoring and its impact on students' academic achievement, formal schooling, and educational inequality in Korea (Doctoral dissertation, Teachers College).

Medway, F. J. (1995). Tutoring. In L. W. Anderson. (Ed.), International encyclopedia of teaching and teacher education, pp. 271-274. Oxford: Pergamon Press.

Memon, N., \& Umrani, S. (2016). The Proliferation of IELTS Preparation Industry of Pakistan. International Research Journal of Arts and Humanities, 44, 33.

Mori, I. (2012). The Effect of Supplementary Tutoring on Students' Mathematics Achievement: A Comparative Study of Japan and the United States.

Muñoz, A. F., Pineda, E. I., \& Radics, A. (2017). EDUCATION at a glance 2017: OECD indicators.

Pallegedara, A. (2012). Demand for private tutoring in a free education country. The case of Sri Lanka. International Journal of Education Economics and Development, 3(4), 375-393.

Porras, D. A., Ee, J., \& Gándara, P. (2014). 10 Employer Preferences: Do Bilingual Applicants and Employees Experience an Advantage? The bilingual advantage: Language, literacy and the US labor market, 99, 234.

Rodríguez, X. (2013). Occupational Purposes model designed for workplace language training in Costa Rica. Revista Comunicación, 15(1), 26-36.

Rosenman, R., Tennekoon, V., \& Hill, L. G. (2011). Measuring bias in self-reported data. International journal of behavioural \& healthcare research, 2(4), 320.

Safarzyńska, K. (2011). Socio-economic determinants of demand for private tutoring. European Sociological Review, 29(2), 139-154.

Sawhney, N., \& Landran, M. (2018). Professional ethics and commitment in teacher education.

Smyth, E. (2008). The more, the better? Intensity of involvement in private tuition and examination performance. Educational research and evaluation, 14(5), 465-476.

Št́astný, V. (2017). Private tutoring lessons supply: Insights from online advertising in the Czech Republic. Compare: A Journal of Comparative and International Education, 47(4), 561-579.

Sujatha, K. (2014). Private tuition in India: trends and issues. Revue internationale d'éducation de Sèvres.

Tanner, E., Ireson, J. M., Rushforth, K., Smith, K., Day, N., Tennant, R., \& Turczuk, O. (2009). Private tuition in England.

Tašner, V., Žveglič, M., \& Čeplak, M. M. (2017). Gender in the teaching profession: university students' views of teaching as a career. Center for Educational Policy Studies Journal, 7(2), 47-69.

Todd, R. W., \& Pojanapunya, P. (2009). Implicit attitudes towards native and non-native speaker teachers. System, 37(1), 23-33.

Torche, F. (2005). Privatization reform and inequality of educational opportunity: The case of Chile. Sociology of education, 78(4), 316-343.

Tosuncuoglu, İ. (2017). Non-Native \& Native English Teachers. Journal of History Culture and Art Research, 6(6), 634-638.

Yung, K. W. H. (2019). Investing in English private tutoring to move socially upward: a narrative inquiry of an underprivileged student in Hong Kong. Journal of Multilingual and Multicultural Development, 1-14. 